\title{
Permacultures of transformation: steps to a cultural ecology of environmental action
}

\author{
Thomas Henfreya,b 1 \\ Lucy Ford \\ ${ }^{\text {a }}$ Schumacher Institute, UK \\ ${ }^{\mathrm{b}}$ Lisbon University, Portugal \\ ${ }^{c}$ Oxford Brookes University, UK
}

\begin{abstract}
This article examines a trend over the past two decades towards more explicit politicization in some areas of the ecovillage movement, particularly where ecovillages engage with related grassroots movements for environmental and social change. It does so using an expanded political ecology framework, also drawing upon 'Multi-Level Perspective on Sustainability Transitions' and Gregory Bateson's Ecology of mind. It argues that apparently apolitical focii on lifestyle change and personal development have in some cases given way to overt recognition of the need for global political change. It attributes this to the global political economy of sustainability becoming more evident and critiques of dominant social, political and economic regimes more compelling and widely accepted.
\end{abstract}

Key words: ecovillages, permaculture, social change, sustainability, transition

\section{Résumé}

Cet article examine une tendance au cours des deux dernières décennies vers une politisation plus explicite dans certains domaines du mouvement écovillage, en particulier lorsque les écovillages s'engagent avec des mouvements de base qui soutiennent le changement environnemental et social. Il le fait en utilisant un cadre d'écologie politique élargi, en s'inspirant également de la «perspective à plusieurs niveaux sur les transitions de durabilité» et de «l'écologie de l'esprit» de Gregory Bateson. Il fait valoir que les priorités apparemment apolitiques sur le changement mode de vie et le développement personnel ont dans certains cas cédé la place à la reconnaissance manifeste de la nécessité d'un changement politique mondial. Il attribue cela à l'économie politique mondiale de la durabilité en devenant plus évident et les critiques des régimes sociaux, politiques et économiques dominants plus convaincantes et largement acceptées.

Mots clés: écovillages, permaculture, changement social, durabilité, transition

\section{Resumen}

Este artículo examina una tendencia en las últimas dos décadas sobre la explícita politización de ciertas áreas del movimiento de ecoaldeas, particularmente donde las ecoaldeas se involucran con movimientos populares relacionados en favor de un cambio social y ambiental. Para lograrlo, se utiliza un marco expandido de ecología política, una perspectiva de Transiciones a la Sustentabilidad a varios niveles, así como de Ecología de la Mente de Gregory Bateson. El artículo argumenta que los enfoques aparentemente apolíticos de cambio en el estilo de

\footnotetext{
${ }^{1}$ Dr. Thomas Henfrey, Centre for Ecology, Evolution and Environmental Change (ce3c), Lisbon University, Portugal and Schumacher Institute for Sustainable Systems, Bristol, UK. Email tom "at" schumacherinstitute.org.uk. Dr. Lucy Ford, Senior Lecturer in International Relations, Department of Social Sciences, Oxford Brookes University, Oxford OX3 0BP, UK. Email: Iford "at" brookes.ac.uk. Thomas Henfrey thanks Claudian Dobos for a thought-provoking conversation on our return journey from the International Permaculture Convergence in London in September 2015, which helped shape some of the ideas in this article. Thanks also to the editors of the Journal of Political Ecology and two anonymous reviewers for their thoughtful and helpful comments. Lucy Ford's fieldwork in Findhorn and Auroville was supported by a grant from the Nuffield Foundation, who are gratefully acknowledged.
} 
vida y desarrollo personal tienen, en algunos casos, una forma de ganar reconocimiento público en favor de la necesidad de un cambio político global. Esto se atribuye a una economía política global de sustentabilidad cada vez más evidente, así como a las críticas a regímenes social, política y economicamente dominantes que resultan cada vez más persuasivas y ampliamente aceptadas.

Palabras Clave: ecoaldeas, transición, permacultura, cambio social, sustentabilidad

\section{Introduction}

The topic of this article is what we are terming 'permanent cultures.' These we define to mean placebased initiatives that seek to create the conditions, cultural and otherwise, for their own persistence into the indefinite future. They do so in ways that, at a minimum, do not prejudice the prospects of such persistence elsewhere and, ideally, enhance these prospects. The term is inspired by permaculture, the term for a design system for sustainable human habitats originally conceived as a contraction of 'permanent agriculture' (Mollison and Holmgren 1978). Permaculture is nowadays more commonly considered to refer to 'permanent culture', taking in an almost indefinite range of material, social and cultural dimensions beyond agriculture (Henfrey and Penha-Lopes 2015). This broader conceptualization, encompassing permaculture's applications in social experiments such as ecovillages, bioregionalism and Transition initiatives, is the one we deploy here (Lockyer and Veteto 2013; Taylor Aiken 2017; Veteto and Lockyer 2008). In particular, this article focuses on ecovillages as key sites for the application, and further development, of permaculture, often in dialogue with Transition and other related movements.

Permaculture originated as a methodology that applies principles derived from careful observation of nature to the conscious design of social and social-ecological systems. It thus seeks to create human habitats that emulate the ways natural systems self-organize for productivity, resilience and adaptability (Holmgren 2002). Crucially, permaculture is located at the intersection of three overlapping ethics, commonly stated as Earth Care, People Care, and Fair Shares, which any application of permaculture must simultaneously fulfill (Aranya 2012).

Ferguson and Lovell (2013) identify present-day permaculture as encompassing four strata:

- the design system itself,

- a body of knowledge and examples of best practice in applying this design system in practice,

- as a worldview that combines the three ethics with the technical imperative of learning from and working with nature,

- and a social movement of self-identified practitioners.

Here we are mostly concerned with the intersections of the latter two strata. Firstly, we identify permaculture's instantiation as a social movement through its uptake in ecovillages and related initiatives, including Transition. Secondly, we trace how within such initiatives, deliberate and conscious changes in worldview can support practical and political action.

Ecovillages are a key vehicle for the practice and development of permaculture. As both ideology and practice, the ecovillage concept has historical connections with older movements in bioregionalism, land stewardship, communitarianism, and countercultural movements of the 1960s (Anderson 2013; Dawson 2006: 12-18). Many ecovillages employ permaculture as a key philosophy and practical methodology and are important sites for permaculture research, demonstration and innovation (Birmbaum and Fox 2014). Some versions of the Ecovillage Design Education course run by Gaia Education, an educational offshoot of the Global Ecovillage Network, incorporate a permaculture design certificate - the basic qualification in permaculture design.

Ecovillages also have close linkages with the Transition movement. Transition is a global movement of local initiatives, originally based on applying permaculture and complementary methodologies in the design of community-based responses to peak oil, climate change and economic instability (Hopkins 2008a, 2011), now encompassing a wider range of approaches to local action for community resilience (Hopkins 2013, 2015). In 
some respects Transition takes innovations and ideas nurtured in the relative isolation of ecovillage life out into the wider world (Lockyer 2010). Ecovillage, Transition and Permaculture networks and organizations were the key drivers behind establishment of the ECOLISE network of European Community-Led Sustainable Initiatives in 2014 , and constitute its core membership. ${ }^{2}$ We here consider ecovillage politics, and in particular changes evident in recent years, in the context of their collaboration in these wider movements for change, and associated action for technological, social and cultural innovation.

\section{Ecovillages and the Global Ecovillage Network (GEN)}

The concept of 'ecovillage' was first formulated in a 1991 report by Diane and Robert Gilman commissioned by the Gaia Trust. It incorporated the following aspects (adapted from Bang 2005):

- human scale (between 50 and 500 people)

- holistic settlement, including food production, manufacture, leisure, social life and commerce (not necessarily completely self-sufficient or isolated from wider society)

- harmless integration of human activities into the natural world (cyclical, rather than linear relationship with nature)

- supportive of healthy human development (balanced and integrated approach to fulfilling human needs: physical, emotional, mental and spiritual)

- sustainable - able to continue indefinitely into the future

The Global Ecovillage Network website offers the following, current definition: ${ }^{3}$

An ecovillage is an intentional or traditional community using local participatory processes to holistically integrate ecological, economic, social, and cultural dimensions of sustainability in order to regenerate social and natural environments.

While Hildur Jackson and Karen Svensson describe them as follows:

Ecovillages embody a way of living. They are grounded in the deep understanding that all things and all creatures are interconnected, and that our thoughts and actions have an impact on the environment...The deep motivation ... is to reverse the gradual disintegration of supportive socio-cultural structures and the upsurge of destructive environmental practices on our planet. (Jackson and Svensson 1990: 10)

Delegates at a conference on the topic of sustainable communities held at Findhorn Ecovillage in Scotland in 1995 agreed to establish the Global Ecovillage Network (GEN) (Dawson 2006). GEN nowadays connects thousands of projects around the world, with regional networks in Africa, Europe, Latin America, North America, and Oceania/Asia. ${ }^{4}$ As well as intentional communities in the Global North and South, it also includes established communities and traditional villages in the Global South, where village living and subsistence-focused local economies are not the distant memories they are for many in the minority world. In some majority world cases, ecovillages have in some cases become alternative models for development on large scales. A major example is the 'thousand villages' project in Senegal, part of the Senegalese government's strategic development policy (Dawson 2013: 225; Jackson 2004).

\footnotetext{
2 www.ecolise.eu

${ }^{3} \mathrm{http}$ //ecovillage.org/en/article/what-ecovillage

${ }^{4}$ https://ecovillage.org/regions/ Accessed 17th Feb 2018.
} 
Despite the rural connotations that the term might infer, ecovillages have also been created in urban environments such as inner city Los Angeles (Birmbaum and Fox 2014: 226-230). Terms like 'communities' or 'settlements' may be more apt than village in such cases. Some urban sustainable living projects such as Lilac Co-Housing in Northern England (Chatterton 2014), while not ecovillages as such, comfortably fit in the wider conceptualization employed here. Similarly, some literature on urban permaculture describes it as a form of 'distributed ecovillage' (Haluza-Delay and Berezan 2013).

Common to all these forms, and implicit in the GEN definition of ecovillages quoted above, is a sense of ongoing exploration and learning. Ecovillage residents Michael Würfel (2012) and Diana Leafe Christian (2012), for example, explicitly characterize their home communities as works in progress. They also equate means with ends: all these initiatives are attempting to work towards building alternative social, cultural, ecological, economic and political structures that serve as living examples of Buckminster Fuller's undertaking to create new possibilities that make existing ways of living obsolete (Leafe Christian, 2012). They are not pretending to have achieved this, and so the possibility always remains that the goal will alter as circumstances change and knowledge progresses.

Our main focus here is a trend in parts of this movement towards increasingly overt politicization of ecovillage development, and how this relates to the role of ecovillages as sites of cultural innovation. This trend has historical roots which predate the formalization of the ecovillage concept, and is still unfolding today. Where it is evident, politicization takes many forms. Some are direct, including GEN's involvement in international sustainability fora. Some are indirect, arising through association with the Transition movement, urban permaculture, and direct action and protest movements. Such changes in the political positioning of ecovillages reflect a deeper trend from a predominant emphasis on personal-as-political to increasingly complementing this with efforts towards wider structural change: from rather inward-looking social and cultural experiments to spaces that actively seek to mobilize and support radical political action towards outcomes consistent with the permaculture ethics of earth care, people care and fair shares.

This trend towards politicization is neither uniform nor universal, or even necessarily general. The primary and secondary data reported in Section 4 below, where we make our empirical case, cover only a very small part of a large and diverse network of mostly autonomous initiatives. Our intention is thus not to generalize about the ecovillage movement as a whole, but to identify, characterize and explain why such changes have taken place in some cases. Doing so illuminates important considerations about the interrelationships of personal development and political activism, and ways in which ecovillages have, in some cases and for some people and groups, become important environments for the exploration of these interrelationships. It also illustrates the more general point that social change has irreducible cultural aspects ranging from the macro-scale need for shifts in predominant worldviews (Göpel 2017) to the importance of micro-scale social dynamics and the nature of the physical settings in which these take place (Maschkowski et al. 2017). Political ecology analyses need to take these into account.

\section{Theoretical framework}

Examining the relationships between micro- and macro-level processes of change requires integrating attention to subjective and intersubjective factors into existing approaches to multi-level analysis. The theoretical framework we use here thus draws on three different approaches: political ecology, The Multi-Level Perspective (MLP) in Sustainability Transitions, and Gregory Bateson's 'ecology of mind.' These have in common that they use organizational hierarchies of one kind or another as analytical devices for understanding change processes. Each approach identifies different kinds of hierarchies, and characterizes levels within them and interactions among these levels in different ways. They also differ in the ways they take account of the wider power dynamics that run through and across organizational hierarchies and scales.

Political ecology foregrounds attention to power relations and their manifestation in cross-scale interactions, particularly the impacts upon local ecologies of wider political and economic factors (Blaikie and Brookfield 1987; Forsyth 2003; Greenberg and Park 1994). It also brings attention to the importance of ecology and nature as conditions within which all human activity necessarily takes place into debates in critical political economy (Ford 2011; Foster, 2009; Gorz 1987). The MLP offers a useful typology of structural scales, and 
insights into patterns of interaction among these (Geels 2002; Grin et al. 2010), but lacks any inbuilt theory of either ecology or the politics of resource degradation. 'Ecology of mind' draws attention to the interdependence of subjective and intersubjective factors (Bateson 1979; Bateson and Bateson 1987). It thus deepens anthropological contributions to political ecology that highlight the importance of the interplay among different understandings of nature (Biersack and Greenberg 2006; Escobar 1999).

The MLP in Sustainability Transitions theory identifies three major analytical levels: niche, regime and landscape. It sees change as arising (or not) due to interactions among these levels, which respectively map on to successively wider extents of power and influence (Geels 2002; Grin et al. 2010). The central level, the sociotechnical regime, consists of the predominant set of infrastructures, practices and associated institutions that support a defined societal function (e.g. food production and allocation, energy generation, transportation). The landscape level represents the background set of cultural norms and expectations and basic societal institutions (such as legal, political and economic frameworks) that express these. Niches are small-scale experiments, isolated from the regime and largely protected from its influence. They provide sources of innovation that can become the basis for establishment of new regimes when changes at landscape level or in wider contextual conditions (such as potential social and/or ecological breakdown) make existing regimes unviable (Seyfang and Smith 2007). Both ecovillages and Transition have been identified as important examples of such 'Grassroots Innovations for Sustainability' (Kunze and Avelino 2015; Seyfang 2009). From a political ecology point of view, we might see these, and related innovations niches such as permaculture, as having arisen in response to the damaging effects of globally dominant regimes of production, governance and development on local ecologies and societies.

The importance of power to interactions of regimes and niches has received increasing attention as the MLP has developed (Geels 2011; Meadowcroft 2005; Smith 2005). Most recently, Avelino (2017) has highlighted the difference between the reinforcive power exerted by incumbent regimes and the innovative power exercised by niches - which under suitable circumstances might translate into transformative power to bring about change and regime and/or landscape levels. Crucially, she notes that many of the crucial resources mobilized in service of all three types of power are psychological and/or cultural. Subjective and intersubjective factors, in other words, crucially determine how power is exercised.

Gregory Bateson's 'ecology of mind' identifies hierarchies of emergent complexity as a common feature of material systems and epistemological frameworks (Bateson 1979; Bateson and Bateson 1987). In other words, just as living organisms are organized as structural hierarchies (Jacob 1989), and ecosystems as nested layers of organizational complexity (Gunderson and Holling 2002; Holling 1992), individual and collective understandings of the world exhibit nested levels of analysis (e.g. Berkes 2008: 8-9; Wilber 2000). This allows processes of understanding and decision-making to shift to a different analytical level, usually more abstract, whenever the problem at hand becomes intractable at the analytical level being employed (Bateson 1972). This explains in conceptual terms the empirically documented linkages between the occurrence and loss of biological and cultural diversity (Maffi 2001). Degradation of the natural world therefore reflects a psychological and cultural impoverishment characteristic of globalized industrial society (Guattari 1992). Our collective ability to understand and respond to environmental and social problems thus depends on diversity of cultural outlook. In other words, innovation in niches can only challenge and hope to transform incumbent regimes, and the social and environmental degradation they create, if it is psychological and cultural as well as material.

In these terms, we can summarize our forthcoming argument as follows. Ecovillages are among the most recent cases of a long history of intentional communities established in response to the perceived inadequacy of dominant regimes. They offer residents increased access to innovative power, in terms of lifestyles, social relationships, and individual and shared understandings of the world. In response to negative ecological and social effects of globally dominant regimes, this innovative power has increasingly been applied to exploring more sustainable lifestyles and the social, psychological and cultural conditions that enable these. More recently, ecovillages and their representative organizations and networks, along with allied movements have sought to confront the reinforcive power of these regimes and in doing so exercise transformative power. This transformative power, whether potential or realized, in part derives from prior innovation in creating spaces for social and cultural innovation and consequent potential for subjective and intersubjective experimentation and 
creativity. This ongoing creation of subjective and intersubjective diversity is, at a global level, a necessary condition for halting and reversing the loss of ecological and biotic diversity. The following sections expand upon this argument in more detail.

\section{Ecovillages as niches for sociocultural experimentation}

The history of ecovillages shows marked shifts in their orientation and outlook, as individual projects have matured, networks have emerged, and wider political and cultural landscapes have changed over time. The trend towards increasingly visible politicization we highlight here reflects a consistent, ongoing trajectory among some settlements towards becoming more engaged with environmental politics and wider environmental movements. Crucial to understanding this trend is Andrew Dobson's distinction between environmentalism and ecologism. Environmentalism is the 'light green' approach to seeking increased sustainability within the scope of existing regimes and landscapes. Ecologism is a more radical, overtly political perspective that sees these regimes and landscapes as inherently environmentally destructive and prospects for change not in their reform, but only in their transformation and replacement (Dobson 2007: 2-3).

Intentional communities have a rather longer documented history than either environmentalism or ecologism. Records go at least as far back as the Homakoien settlement of heterodox intellectuals and mystics founded by Pythagoras and followers in 525 BCE (Metcalf 2012). An apparently consistent feature is that residents enact critiques of wider society by creating lived alternatives, typically based around shared mystical or spiritual narratives (Brown 2002). This is certainly true of some of the older members of GEN like Findhorn (Scotland), Tamera (Portugal, see Esteves 2017), Damanhur (Italy), Lama (USA) and Auroville (India), some of which are over fifty years old. All started life as experiments in alternative lifestyles and spirituality. Interest in sustainability arose later and in some cases remains secondary to their spiritual purpose, though all have become exemplars of more sustainable ways of life and in some cases sustainability has become their main concern (e.g. Birmbaum and Fox 2014). Sustainability has been the key interest behind the establishment of many newer settlements - the mission statement of Dancing Rabbit Ecovillage in Missouri, USA, for example, states that its key purpose is to support its members to live sustainably (Lockyer 2017). However, consistent with the socially transgressive implications of ecologism, residents highlight as key not more sustainable outcomes themselves, nor even experimentation in search of them, but the structures and social processes that make them possible (Christian 2012; Metcalf 2012; Würfel 2012). The change thus appears to be one of degree rather than kind, reflecting the growing urgency of environmental issues and their consequent importance in radical politics.

Ford gathered data via interviews, participant observation and use of literature at two institutional members of GEN - Findhorn and Auroville - during 2004 and 2005. ${ }^{5}$ Her findings show the diversity of relationships that inhabitants have with transformative politics. On the one hand there was evidence that these communities were inwardly focused towards community-building and personal growth; on the other there was also evidence that they saw themselves as agents of change to a more sustainable, fairer society. While many of the interviewees saw change as a personal individual journey, some did identify with a wider political movement for social change. Some were active participants at World Social Fora and other nodes of action and activism. There was an emphasis on affirming positive, alternative lifestyles in keeping with a green/spiritual/holistic vision rather than an 'anti' or 'resistance' mindset. Both these communities have deep spiritual roots, which perhaps explains their strong focus on individual personal transformation and change. Nevertheless, both are also committed to global education and outreach, as evidenced by their engagement in GEN and wider educational projects such as Gaia Education at Findhorn, to which we return below, and Auroville's establishment of the University of Human Unity in 2006.

\footnotetext{
${ }^{5}$ This research was funded by a small grant from the Nuffield Foundation and has not previously been published. Participant observation and interviews took place during an ecovillage experience week in Findhorn in October 2004 and a research trip to Auroville in January 2005. In Auroville semi-structured interviews were conducted with 12 residents. As with all ethnographic research, it cannot be assumed that these individuals are representative of the community of Auroville, much less the ecovillage movement as a whole.
} 
Newer ecovillages like Sieben Linden in Saxony, Zegg in North Eastern Germany and Lammas in Wales encapsulate explicit forms of green political radicalism. Their historical roots extend beyond the ecovillage movement and ecologist politics. Many have links with the DIY culture that, in the UK at least, arose out of countercultural movements in the 1960s and propagated at the margins of society in 'Temporary Autonomous Zones' (TAZ): squats, festivals, protest camps, new age traveler movements and illegal parties that provided ephemeral spaces which birthed and nurtured new 'cultures of resistance.' Such spaces had instrumental roles in the origins of road protests and other direct action movements of the 1990s (McKay 1996). Lammas ecovillage in West Wales, for example, originated in relationships and ideas arising at Dance Camp Wales, a long-standing annual TAZ. Many former road protesters and the like are now active in permaculture, Transition and Low Impact Development, and small scale intentional communities dedicated to sustainable living. These have been kept on the margins of society by restrictions in national planning law (Fairlie 2009; Pickerill 2013). Later, so-called 'anti-globalization' protests such as those in Seattle, Genoa and Prague between 1999 and 2001 catalyzed formation of new settlements and residential projects. Escanda in Northern Spain and Can Mas Deu in Barcelona are examples of communities established in the wake of these protests to provide permanent spaces for discussion and enactment of political programs, underlying and inspired by the protests.

In summary, a historical examination of ecovillages supports the argument that they operate as niches, sufficiently isolated from the demands of wider society to provide spaces for social, cultural and lifestyle experimentation. The nature of this experimentation has, for many ecovillages, changed over time in response to shifting political landscapes and the growth of ecologism as a political philosophy. Change has also been evident in relationships between some ecovillages and wider society, particularly as environmentalism has gained prominence in mainstream political agendas and ecologism has grown as a political movement. These changes are the subject of the next section.

\section{Beyond the ecovillage: Transition and empowered niches}

Haxeltine et al. (2008) augment the original form of the MLP with a fourth level: the 'empowered niche.' An empowered niche (or 'niche-regime' - an intermediate form with features of both those levels) arises when a niche acquires enough power (support, resources, etc.) to become a potential threat or alternative to the incumbent regime. The concept provides a useful lens through which to examine the growth since around 2005 of grassroots community-based sustainability initiatives, where groups of people self-organize within communities of place to take action at the interface of local issues and global sustainability concerns.

Historical and ongoing influences upon these community-led sustainability initiatives are diverse. Many have roots in the Local Agenda 21 program set up following the first Rio Earth Summit in 1992. Some result from the actions of local groups associated with international NGOs like Friends of the Earth. Many are influenced by and/or have close links with either specific ecovillages or other significant organizations and networks within the ecovillage movement. Our argument here will be that the capacity of such initiatives to mobilize transformative power is in part a product of social and cultural innovation of the type fostered in many ecovillages.

Transition can be seen as transposing to existing settlements ideas and practical actions originating and/or more commonly found in ecovillages (Lockyer 2010). Permaculture is a common factor, both as a key concept and as a tool for practical action. Transition originated when a group of permaculture students taught by Rob Hopkins at Kinsale College in Ireland designed a community-led response to peak oil as their end of course project (Hopkins 2005). Hopkins subsequently relocated to Totnes in Southwest England and there cofounded the world's first Transition Initiative and subsequently Transition Network, a coordination and support organization for similar initiatives in other places. Transition has since grown into a worldwide movement with over 1,000 reported initiatives in over forty countries. ${ }^{6}$ Transition highlights permaculture as a key feature of its methodology (Hopkins 2011: 98-99). Many writers on permaculture cite Transition among its key social applications (Aranya 2012: 88; MacNamara 2013: 195-199; Henfrey and Penha-Lopes 2015: 57-60).

\footnotetext{
${ }^{6}$ www.transitionnetwork.org/initiatives
} 
Ecovillages, Low Impact Developments, and permaculture projects have often acted as physical bases supporting the establishment and growth of Transition in their area.

Studies within the 'sustainability transitions' field have identified Transition initiatives as important socio-technical niches, supporting innovation in areas such as community energy and alternative currencies (Seyfang 2009). In certain respects these and related forms of community action are beginning to exhibit features of empowered niches, in their ability to challenge and to some degree exert change upon incumbent regimes (Butler et al. 2013). Transition came into being with the explicit goal of bringing about wide-ranging and deep-rooted change. This change was initially framed as constructive local responses to peak oil and climate change, and more recently as a more generalized form of social critique and call to action (Hopkins 2013).

Many ecovillages nowadays foreground aspirations similar to those of Transition, as GEN builds a global network of best practice and engages with dominant institutions as well as other grassroots social movements (Dawson 2013). Findhorn has a vast educational program, part of a strong focus on outreach, and is the base for Gaia Education, founded in 2005 as a vehicle for the Ecovillage Design Education course. It actively engages with state and interstate institutions such as UNITAR (United Nations International Training Centers for Local Actors), which designated Findhorn as a training center for education on environmental planning and sustainable development. In 1998 Findhorn was awarded the UN Habitat Best Practice Designation, demonstrating sustainable methods of building, heating, and waste water treatment. Many ecovillage residents regard exploration and demonstration of possibilities for less resource-intensive, more sustainable ways of life as among their most important roles (Christian 2012; Würfel 2012).

Permaculture's self-organization as a movement is also increasing in ambition and complexity. At the $11^{\text {th }}$ International Permaculture Convergence (IPC) in 2013, Permaculture's 'Next big step' began as an inclusive strategic conversation about the future of permaculture on a global scale and its engagement with the wider world. ${ }^{7}$ These conversations were an important part of the program at the subsequent IPC in London in 2015. In 2014, GEN, Transition Network and national associations representing permaculture, ecovillages and Transition initiatives from across Europe established ECOLISE, a new organization to promote collaboration, support and mutual learning and provide a common political platform at European level. ${ }^{8}$ All these developments represent an emergence of new levels of organizational complexity with increasing resemblance to the features of empowered niches. These new organizational forms also have characteristics that are not easily accommodated in the MLP, even in its extended form. Their understanding thus requires a broader analytical framework. The next section begins to build such a framework as it locates developments in the relationships of the ecovillage and Transition movements in changes taking place over the past decade in the wider political economy of climate change.

\section{Climate activism and climate politics}

If GEN was founded amidst post-Rio optimism, Transition arose at a time when the twin prospects of climate change and peak oil made significant change at regime and landscape levels appear inevitable. ${ }^{9}$ In retrospect, 2008 and 2009 seem like heady days for those involved in Transition. The importance and sheer common sense of the core message - that serious unavoidable problems are best addressed proactively in ways that make a virtue of the need for systemic change - seemed to resonate at the highest levels of policy. With the publication of landmark macroeconomic analyses like Prosperity without growth (Jackson 2009), the financial crisis of 2008 and 2009 appeared to provide the strongest possible demonstration of the need for radical overhaul of the global economy. However, the reality proved far different: inspired by Al Gore's brand of climate capitalism, corporate powers had already taken steps to foreclose significant changes at regime and landscape levels and to ensure international responses to climate change reinforced rather than challenged financial 'business as usual' (Noble 2007). With hindsight, the failure of the 2009 United Nations Climate Change

\footnotetext{
${ }^{7}$ https://international.permaculture.org.uk

${ }^{8}$ www.ecolise.eu

${ }^{9}$ An example of the type of analysis that influenced such conclusions can be found in Holmgren, D. 2008. Future scenarios. Totnes: Green Books.
} 
Conference in Copenhagen appears predictable, and the hope that preceded it to reflect naivete about the power of the vested interests that constrain international political processes.

Transition was criticized in its earliest days for an apparently apolitical approach (Chatterton and Cutler 2008). Debate on the blog of Transition founder Rob Hopkins suggested this position was more pragmatic than ideological: adopted to maximize inclusion and transcend traditional boundaries of political affiliation (Hopkins 2008b). The understanding that a society that prioritizes wellbeing within environmental limits will have social, economic and political institutions very different from those of the present day is far older than Transition (Douthwaite 1996; Ekins 1986; Heinberg 2005; Schumacher 1973), and was in fact prominent in the movement from the start. Transition Network's earliest literature dismissed any prospect of governments instigating timely and meaningful change. If at that point the Transition model was politically ingenuous, it was also underestimating governments' will and ability to impede such change (Alloun and Alexander 2014).

Underestimating barriers to change has had consequences at individual and group levels. Individually, Transition activists have often experienced emotional and physical burnout as a result of overexertion. Many have found themselves not the catalyst that unleashes a wave of energy in their community, but as indispensable protagonists in more activities than any one person can sustain. At a collective level, many initiatives have failed to grow or to realize initially lofty ambitions. Instead they have persisted at lower levels of activity, gone into indefinite periods of hibernation or disappeared altogether. Some have experienced what has become known as the 'doughnut effect': all available time and energy go into key projects, the core organizers of these project have little left to contribute to central coordination and group maintenance, and the place these functions previously occupied within the initiative becomes a void. In the UK, where Transition has the longest history, an initial phase of growth gave way to one of drop-off and subsequent reorganization (Henfrey and Giangrande 2017). The movement as a whole has continued to grow, but in recent years most of this growth has been outside the UK. A similar experience is reported from GEN, whose COP15 coordinator experienced burnout in the runup to the Copenhagen talks resulting from attempts to exceed GEN's capacity at the time (Hall 2015).

This relative naivete about the nature and effects of reinforcive power is mirrored in the literature on sustainability transitions, whose original forms failed adequately to consider power (Shove and Walker 2007, 2008). Addressing this, Avelino and Rotmans (2009) incorporate power into the MLP as a function of various capacities to mobilize resources, both material and non-material. These capacities include:

- innovative power - to create or discover new resources

- destructive power - to remove resources

- constitutive power - to create new frameworks (institutional or infrastructural) for the deployment of resources

- and transformative power - to transform patterns of resource distribution on any scale.

Exercising power in any of these forms depends not only on access to resources but upon strategies and methods to deploy them, skills to enact these strategies, and a willingness to do so. This framework characterizes niches as networks of actors able to exercise innovative power and/or destructive power. It sees empowered niches as having additional acquired transformative power. This may be through effective networking or collaboration, or through the support of regime actors already able to exercise transformative power. More recent developments replace the concept of constitutive with that of reinforcive power - that of regimes to resist or undermine change - and points out that different actors at niche and/or regime level may be seeking to mobilize different kinds of resources (Avelino 2017). The power exercised by regime actors may thus interact with that available at niche level in complementary, neutral or antagonistic ways, depending on circumstances.

Empowerment as it relates to niches is thus a systemic property: it depends on the properties of the niche itself and its relationship to the wider context. Relevant contextual factors include, in addition to the interactions with regime and landscape described by the MLP, many forms of interaction across levels and scales highlighted in political ecology frameworks. Current pluralistic forms of political ecology emphasize that these interactions have crucial intersubjective dimensions: they encompass distinct, often conflicting cultural understandings of 
human-nature relationships (Biersack and Greenberg 2006; Escobar 2006). An 'ecology of mind' framework suggests that, in line with Avelino's most recent analysis, these cultural differences may reflect - and underpin - differences in the types of power held by different groups of actors and their ability to exercise these. Experiences such as individual burn-out and disappearance of groups may, at least in part, reflect a relative inability of people and groups to locate, develop and/or maintain cultural or sub-cultural environments conducive to identifying or mobilizing relevant forms of innovative and or transformation power, particularly those relating to personal and social resources.

As important as these inner dimensions are, they are not separate from external structures. Critical political ecological analyses remind us of the deeper hegemonic structures of modernity that require transformation, for example challenging entrenched capitalist and neoliberal economic discourse (Foster 2009). However, most of these critiques lack adequate appreciation of the inner dimensions of change. What is required then, are hybrid approaches that explore both inner and outer aspects of progressive social change. This relationship between inner and outer aspects of change work is the heart of our argument here, and the topic of the next section.

\section{Towards a transformative ecology of mind}

This section explores the interplay between inner and outer dimensions of change. It adds to our theoretical framework and Bateson's (1979) recognition of organizational and processual features common to both 'mind and nature' (i.e. to the subjective and objective dimensions of any phenomenon). Building on Bateson, Guattari (1992) identified 'three ecologies', referring to three domains of action towards a just and sustainable society: ecological, social and subjective. These theoretical observations underpin our central point in this section: that the cultural innovation undertaken in ecovillages and related movements is a vital component of social change. This is because it is a necessary correlate to structural (external) change, and also because it allows creation of environments conducive to the wellbeing of change activists whose work is likely to expose them to psychological pressure.

Consideration of the cultural ecology of indigenous and traditional peoples is instructive here, for two main reasons. First, a wealth of anthropological study has provided a substantial base of empirical knowledge and relatively sophisticated theoretical understanding of the role of culture in structuring human-environment relations (e.g. Anderson 2010; Descola and Pálsson 1996; Ellen and Fukui 1996). Second, huge differences of history and present circumstances notwithstanding, important common ground exists between grassroots movements for sustainability (such as ecovillages, Transition and permaculture) on the one hand, and indigenous or traditional peoples living in largely land-based and/or subsistence-oriented economies (Henfrey and Kenrick 2017; Henfrey and Penha-Lopes 2015: 27-29; Kuecker 2017). They have in common that they seek either to maintain or to create social and economic systems based on premises, goals and processes very different from those of dominant regimes and landscapes. Very often, these take the form of commons - material or intangible resources self-managed by their co-users according to agreed bundles of rights, responsibilities and governance procedures (Berkes 1989; Bollier and Helfrich 2012; Ostrom 1990).

Traditional commons intimately link social and economic structures with ecological and cultural idiosyncrasies of place (Berkes and Folke 1998; Bromley et al. 1992). They comprise sets of institutions for making decisions and allocating rights and responsibilities over use of resources finely tuned to local conditions (Ostrom 2005). Such commons, and the resources they encompass, are the basis for biocultural diversity - the geographical co-occurrence and material interdependence of biological and cultural diversity (Maffi 2001). Cultural differences not only reflect variation in environmental and ecological conditions, but they extend and perpetuate them through anthropic influences on local environments (Balée 1998; Balée and Eriksen 2006). In their efforts to ground local economies in ecological realities and to create the social mechanisms and cultural understandings necessary for bioregional and other place-based economies to operate effectively, ecovillages and related environmental movements have, in our view, become a network of experiments in the deliberate generation of biocultural diversity. In the multi-level analytical framework we are using here, this finding illuminates the relationships among micro-scale sociocultural realities on the one hand, and political forces constituted primarily at national and international levels on the other. 
Where indigenous groups confronting assimilation into national and global economies have maintained their capacity for economic self-determination by managing resources as commons, this depends in every case on their ability to exercise social and cultural autonomy. Except for the few groups still too geographically remote to experience either direct state influence or incursions from ecologically damaging extractive industries, such autonomy depends on the existence in state legislation and regulation of suitable enabling frameworks. An example is the recognition in Mexican national law of indigenous land tenure and the right of indigenous groups to exercise traditional systems for allocating usage rights (Alcorn and Toledo 1998). These 'institutional shells' insulate traditional systems from the demands of state property law. They allow indigenous villages to organize autonomously and integrate into national economic and political systems on their own terms, exercising cultural self-determination and contributing to resilient regional economies (Toledo 2001). For non-indigenous movements seeking to create new commons as organizational bases for sustainability and equity, cooperative law often fulfills a similar function. Many ecovillages have as their legal basis a land-owning co-operative, and many enterprises based in ecovillages or associated with Transition initiatives operate as cooperatives. The absence of institutional shells can be problematic, or at the very least require high levels of resourcefulness. For example, a survey of permaculture farms in the USA revealed a wide range of strategies to buffer impacts of hostile wider political and economic environments; in very few cases was this sufficient for them to have become financially robust (Ferguson 2014).

Another vital component of effective indigenous self-governance is cultural self-determination. This factor also seems relevant to radical social change movements confronting the entrenched ideologies of incumbent regimes and their ability to exercise reinforcive power. Traditional belief is central to indigenous environmental management: it encodes collective knowledge and provides emotionally compelling motivation for individual action (Anderson 1996; Berkes 2008). Similarly, intellectual understanding of environmental issues translates into meaningful action (which often involves personal cost or risk) only when it becomes more deeply experienced as a form of emotional commitment to the natural world (Milton 2002).

For some, this implies a spiritual or mystical component to activism (Harvey 2009; McIntosh and Carmichael 2016). However, overt spirituality is only one possible form of what Bateson referred to as 'the sacred' (Bateson and Bateson 1987). To list a few well-documented examples: re-exploring the Quaker tradition of socially conscious action in the light of sustainability concerns has enabled radical lifestyle changes on the part of many individual chapter members in the UK, in some cases reducing carbon budgets to 20 per cent of the national average, and waste consumption to as little as 5 per cent (Michaelis 2008). Development and uptake of wind power technologies and establishment of the manufacturing sector in Denmark were rapid and widereaching because of their grounding in a long-standing cultural tradition of cooperative ownership of infrastructure (van Est 1999). Uptake of permaculture has revitalized many traditional Latvian smallholdings, facilitated by a resonance between traditional values and the interface of permaculture's 'earth care' and 'people care' ethics (Aistara 2013). The Russian smallholding movement has in the past two decades explicitly aligned itself with the permaculture movement and at the same time adopted as a guiding narrative the spiritual and philosophy (and its practical applications) described in the Ringing cedars book series. These books describe the life and philosophy of the apparently mythical Anastasia, who lives deep in the Siberian forest in a state of harmony with nature and advanced physical, intellectual and spiritual development (Birmbaum and Fox 2014: 312-315). What links all of these, regardless of their specific form, is that they combine aspirations to be materially transformative of incumbent regimes with adherence to strongly transgressive worldviews.

Supportive cultures of resistance are not just a structurally necessary correlate to transformative power: they are also an essential enabling context for individual emotional health and personal resilience. Successful activism requires safe and nurturing environments conducive to acknowledgement and expression of the emotional vulnerabilities often exposed by rejecting and directly challenging dominant cultural norms and values (Brown and Pickerill 2009). Developing, locating and inhabiting such salutogenetic environments (i.e., settings supportive of personal mental health) is key to the capacity of pioneers in many different forms of activism to sustain their personal involvement (Maschkowski et al. 2017). Sometimes this has apparently been spontaneous, as in the elaborate, intertwined personal and group mythologies that arose among long-term road protesters at several different sites in England in the 1990s (Butler 1996; Letcher 2001). The cultural 
experiments that characterized many early ecovillages and other historical intentional communities were perhaps of a similar ilk. They may be the forerunners of the more sophisticated approaches employed today in social permaculture (MacNamara 2013) and Inner Transition (Baker 2011), and taught in the social and cultural pillars of the Ecovillage Design Education course. ${ }^{10}$ Rather than being distractions from practical and political goals, hindsight now reveals them to be vital underpinnings of any form of radical political action. Their maturity allows present-day forms of radical environmentalism to raise their ambitions in a realistic fashion, and to act upon these ambitions with the security and conviction that a solid subcultural grounding allows.

\section{Conclusion: creating transformative cultures}

In conclusion, we argue that a major legacy of several decades of cultural innovation within ecovillages is the ecovillage movement becoming an empowered niche able to harbor realistic aspirations for the exercise of transformative power. This cultural innovation, and its continuation and extension within related movements not necessarily associated with residential communities such as permaculture and Transition, is also a crucial factor enabling possible mobilization of transformative power in these movements. The intellectual and ideological battles for sustainability were won decades ago, to the extent that environmentalist rhetoric is evident in national and international discourses on policy involving probably every government in the world. These apparent victories have so far remained pyrrhic, insofar as this rhetoric has reinforced rather than undermined globally dominant cultural perspectives and associated narratives based on commodifying nature and social life, competition, and the myth of perpetual economic growth. Arguments for genuine transformation to a global society not systemically reliant on catastrophic environmental and social damage and inexorable increases in inequality, however reasonable and grounded in evidence, can gain no traction against a landscape still dominated by these collective fantasies. Alternative cultural stories around which new belief systems consistent with contemporary scientific understandings of terrestrial ecology could emerge have been developing for some time - in far more than the relatively narrow range of settings we consider here (Eisenstein 2013; Paulson 2017). Our optimistic assessment is that they are now reaching the point where this global cultural shift becomes a tangible possibility. The accuracy of this assessment notwithstanding, our key point is that these cultural dimensions of innovation within niches are a vital component of any possible shift to sustainability and equity as key principles of global governance.

\section{References}

Alloun, E. and S. Alexander. 2011. The Transition movement. Simplicity Institute Report 14g. Melbourne: Simplicity Institute.

Aistara, G. 2013. Weeds or wisdom? Permaculture in the eye of the beholder on Latvian eco-health farms. In Lockyer, J. and J. Veteto (eds.) Environmental anthropology engaging ecotopia: bioregionalism, permaculture and ecovillages. New York and Oxford: Berghahn Books.

Alcorn, J.B. and V.M. Toledo. 1998. Resilient resource management in Mexico's forest ecosystems: the contribution of resource rights. In Berkes, F. and C. Folke (eds.) Linking social and ecological systems. management practices and social mechanisms for building resilience. Cambridge: Cambridge University Press.

Anderson, E. 1996. Ecologies of the heart. Oxford: Oxford University Press.

Anderson, E. 2010. The pursuit of ecotopia: lessons from indigenous and traditional societies for the human ecology of our modern world. Westport: Praeger.

Anderson, E. 2013. Foreword. In Lockyer, J. and J. Veteto (eds.) Environmental anthropology engaging ecotopia: bioregionalism, permaculture and ecovillages. New York and Oxford: Berghahn Books.

Aranya. 2012. Permaculture design: a step-by-step guide. East Meon: Permanent Publications.

${ }^{10}$ See www.gaia.org/gaia/education/curriculum/ 
Avelino, F. 2017. Power in sustainability transitions: analysing power and (dis)empowerment in transformative change towards sustainability. Environmental Policy and Governance 27(6): 505-520.

Avelino, F. and J. Rotmans. 2009. Power in transition: an interdisciplinary framework to study power in relation to structural change. European Journal of Social Theory 12(4): 543-569.

Baker, C. 2011. Navigating the coming chaos: a handbook for inner transition. Bloomington, IN: iUniverse.

Balée, W.L. (ed.). 1998. Advances in historical ecology. New York: Columbia University Press.

Balée, W.L. and C.L. Erickson (eds.). 2006. Time and complexity in historical ecology. New York: Columbia University Press.

Bang, J.M. 2005. Ecovillages: a practical guide to sustainable communities. Bath: Bath Press.

Bateson, G. 1972. Steps to an ecology of mind. Chicago: University of Chicago Press.

Bateson, G. 1979. Mind and nature: a necessary unity. London: Fontana.

Bateson, G. and M.C. Bateson. 1987. Angels fear: towards an epistemology of the sacred. New York: Bantam.

Berkes, F. (ed.). 1989. Common property resources: ecology and community-based sustainable development. London: Belhaven Press.

Berkes, F. 2008. Sacred ecology. Second edition. London: Routledge.

Berkes, F. and C. Folke (eds.). Linking social and ecological systems. management practices and social mechanisms for building resilience. Cambridge: Cambridge University Press.

Biersack, A. and J.B. Greenberg (eds.). 2006. Reimagining political ecology. Durham, NC: Duke University Press.

Birmbaum, J. and L. Fox. 2014. Sustainable revolution: permaculture in ecovillages, urban farms, and communities worldwide. Berkeley: North Atlantic Books.

Blaikie, P.M. and H.C. Brookfield. 1987. Land degradation and society. London: Methuen.

Bollier, D. and S. Helfrich (eds.). 2012. The wealth of the commons: a world beyond market and state. Amherst, MA: Levellers Press.

Bromley, D.W. (ed.). 1992. Making the commons work: theory, practice, policy. San Francisco: Institute for Contemporary Studies Press.

Brown, S.L. 2002. Intentional community: an anthropological perspective. New York: SUNY Press.

Brown, G. and J. Pickerill. 2009. Editorial: activism and emotional sustainability. Emotion, Space and Society 2: $1-3$.

Butler, B. 1996. The tree, the tower, and the shaman: the material culture of resistance of the No M11 Link Roads Protest of Wanstead and Leytonstone. Journal of Material Culture 1(3): 337-363.

Butler, C., S. Darby, T. Henfrey, R. Hoggett and N. Hole. 2013. People and communities in energy security. In C. Mitchell, J. Watson and J. Whiting (eds.) New challenges in energy security: the UK in a multipolar world. London: Palgrave MacMillan.

Chatterton, P. 2014. Low impact living: a field guide to ecological, affordable community building. London: Earthscan.

Chatterton, P. and A. Cutler. 2008. The rocky road to a real transition: the Transition Towns Movement and what it means for social change. Trapese Collective.

Christian, D.L. 2012. We never lock our doors. RCC Perspectives 8: 18-19.

Dawson, J. 2006. Ecovillages: new frontiers for sustainability. Schumacher Briefings no. 12. Dartington: Green Books.

Dawson, J. 2013. From islands to networks: the history and future of the Ecovillage Movement. In Lockyer, J. and J. Veteto (eds.) Environmental anthropology engaging ecotopia: bioregionalism, permaculture and ecovillages. New York and Oxford: Berghahn Books.

Descola, P. and G. Pálsson (eds.). 1996. Nature and society. London: Routledge.

Dobson. A. 2007. Green political thought. Fourth Edition. London: Routledge. 
Douthwaite, R. 1996. Short circuit: strengthening local economics for security in an unstable world. Dublin: Lilliput Press.

Ekins, P. (ed.). 1986. The living economy. London: Routledge.

Ellen, R.F. and K. Fukui (eds.). 1996. Redefining nature. Oxford and Washington: Berg.

Escobar, A. 1999. After nature: steps to an antiessentialist political ecology. Current Anthropology 40(1): 1-30.

Escobar, A. 2006. Difference and conflict in the struggle over natural resources: a political ecology framework. Development 49(3): 6-13.

Esteves, A.M. 2017. "Commoning" at the borderland: ecovillage development, socio-economic segregation and institutional mediation in southwestern Alentejo, Portugal. Journal of Political Ecology 24: 968-991.

Fairlie, S. 2009. Low impact development: people and planning in a sustainable countryside. Second edition. Charlbury: Jon Carpenter.

Ferguson, R.S. 2014. Toward 21st century permaculture: critical questions and early answers. Permaculture Activist 93.

Ferguson, R.S. and S.T. Lovell. 2013. Permaculture for agroecology: design, movement, practice, and worldview: a review. Agronomy for Sustainable Development 34(2): 251-274.

Ford, L.H. 2013. EU trade governance and policy: a critical perspective. Journal of Contemporary European Research 9(4): 578-596.

Forsyth, T.J. 2003. Critical political ecology: the politics of environmental science. London: Routledge.

Foster, J.B. 2009. The ecological revolution: making peace with the planet. New York: Monthly Review Press.

Geels, F. 2002. Technological transitions as evolutionary reconfiguration processes: a multi-level perspective and a case study. Research Policy 31: 1257-1274.

Geels, F. 2011. The multilevel perspective on sustainability transitions: responses to seven criticisms. Environmental Innovation and Societal Transformations 1: 24-40.

Göpel, M. 2017. Shedding some light on the invisible: the transformative power of paradigm shifts. In Henfrey, T., G. Maschkowski and G. Penha-Lopes (eds.) Resilience, community action and societal transformation. East Meon: Permanent Publications.

Gorz, A. 1987. Ecology as politics. London: Pluto Press.

Greenberg, J.E. and T.K. Park. 1994. Political ecology. Journal of Political Ecology 1(1): 1-12.

Guattari, F. 2000 (1989). The three ecologies. Translated by I. Pindar and P. Sutton. London: Athlone.

Gunderson, L.H. and C.S. Holling (eds.). 2002. Panarchy. Washington DC: Island Press.

Hall, R. 2015. COP21: is a major societal shift this December possible? [accessed Feb $1^{\text {st }}$ 2018]. https://geneurope.org/news-events/archive/latest-news/cop21-is-a-major-societal-shift-this-decemberpossible/index.htm

Haluza-Delay, R. and R. Berezan. 2013. Permaculture in the city: ecological habitus and the distributed ecovillage. In Lockyer, J. and J. Veteto (eds.) Environmental anthropology engaging ecotopia: bioregionalism, permaculture and ecovillages. New York and Oxford: Berghahn Books.

Harvey, A. 2009. The hope: a guide to sacred activism. Carlsbad: Hay House.

Haxeltine, A., L. Whitmarsh and N. Bergman. 2008. A conceptual framework for transition modelling. International Journal of Innovation and Sustainable Development 3(1/2): 93-114.

Heinberg, R. 2003. The party's over: oil, war and the fate of industrial societies. Gabriola Island: New Society Publishers.

Henfrey, T. and G. Penha-Lopes. 2015. Permaculture and climate change: inspiring social, ecological, economic and cultural responses. East Meon: Permanent Publications.

Henfrey, T. and J. Kenrick. 2017. Climate, commons and hope: the Transition movement in global perspective. In Henfrey, T., G. Maschkowski and G. Penha-Lopes (eds.) Resilience, community action and societal transformation. East Meon: Permanent Publications. 
Henfrey, T. and N. Giangrande. 2017. Resilience and community action in the Transition Movement. In Henfrey, T., G. Maschkowski and G. Penha-Lopes (eds.) Resilience, community action and societal transformation. East Meon: Permanent Publications.

Holmgren. D. 2002. Permaculture: principles and practices beyond sustainability. Melliodora: Holmgren Design Services.

Holmgren, D. 2008. Future scenarios. Totnes: Green Books.

Hopkins, R. (ed.). 2005. Kinsale 2021: an energy descent action plan. [accessed Feb $1^{\text {st }} 2018$ ]. http://www.transitionus.org/sites/default/files/KinsaleEnergyDescentActionPlan.pdf

Hopkins, R. 2008a. The Transition handbook. Totnes: Green Books.

Hopkins, R. 2008b. The rocky road to a real transition: a review. [accessed Feb $1^{\text {st }} 2018$ ]. http://transitionculture.org/2008/05/15/the-rocky-road-to-a-real-transition-by-paul-chatterton-andalice-cutler-a-review/

Hopkins, R. 2011. The Transition companion. Totnes: Green Books.

Hopkins, R. 2013. The power of just doing stuff. Cambridge: UIT/Green Books.

Hopkins, R. 2015. 21 stories of Transition. Totnes: Transition Network.

Holling, C.S. 1992. Cross-scale morphology, geometry, and dynamics of ecological systems. Ecological Monographs 62(4): 447-502.

Jackson, H. and K. Svensson. 1990. Ecovillage living: restoring the earth and her people. Totnes: Green Books.

Jackson, R. 2004. The ecovillage movement. Permaculture Magazine 40 (Summer 2004).

Jackson, T. 2009. Prosperity without growth. London: Earthscan.

Jacob, F. 1989. The logic of life. London: Penguin.

Keucker, G. 2017. Enchanting Transition: a post colonial perspective. In Henfrey, T., G. Maschkowski and G. Penha-Lopes (eds.) Resilience, community action and societal transformation. East Meon: Permanent Publications.

Kunze, I. and F. Avelino. 2015. Social innovation and the global ecovillage network. Research Report, TRANSIT: EU SSH.2013.3.2-1 Grant agreement no: 613169.

Letcher, A. 2001. The scouring of the shire: fairies, trolls and pixies in eco-protest culture. Folklore 111(2): 147-161.

Lockyer, J. 2010. Intentional community carbon reduction and climate change action: from ecovillages to transition towns. In Peters, M., S. Fudge and T. Jackson (eds.). Low carbon communities. Cheltenham: Edward Elgar.

Lockyer, J. 2017. Community, commons, and degrowth at Dancing Rabbit Ecovillage. Journal of Political Ecology 24: 519-542.

Lockyer, J. and J. Veteto (eds.). 2013. Environmental anthropology engaging ecotopia: permaculture, ecovillages and bioregionalism. Oxford: Berghahn.

MacNamara, L. 2013. People and permaculture. East Meon: Permanent Publications.

Maffi, L. (ed.). 2001. On biocultural diversity: linking language, knowledge and the environment. Washington and London: Smithsonian Institution Press.

Maschkowski, G., N. Schäpke, J. Grabs and N. Langen. 2017. Learning from co-founders of grassroots initiatives: personal resilience, transition, and behavioral change - a salutogenic approach. In Henfrey, T., G. Maschkowski and G. Penha-Lopes (eds.) Resilience, community action and societal transformation. East Meon: Permanent Publications.

McIntosh, A. and M. Carmichael 2016. Spiritual activism: leadership as service. Cambridge: UIT.

McKay, G. 1996. Senseless acts of beauty: cultures of resistance since the sixties. London: Verso.

Meadowcroft, J. 2011. Engaging with the politics of sustainability transitions. Environmental Innovations and Societal Transitions 1: 70-75. 
Metcalf, W.J. 2012. Utopian struggle: preconceptions and realities of intentional communities. RCC Perspectives 8: 21-29.

Michaelis, L. 2008. Quaker simplicity. In Bouckaert, L., H. Opdebeeck and L. Zsolnai (eds.) Frugality: rebalancing material and spiritual values in economic life. Bern: Peter Lang.

Milton, K. 2002. Loving nature: towards an ecology of emotion. London: Routledge.

Mollison, B. and D. Holmgren. 1978. Permaculture one: a perennial agriculture for human settlements. Tyalgum: Tagari Publications.

Noble, D. 2007. The corporate climate coup. [accessed Feb 1 ${ }^{\text {st }}$ 2017]. https://zcomm.org/znetarticle/thecorporate-climate-coup-by-david-f-noble

Ostrom, E. 1990. Governing the commons. Cambridge: Cambridge University Press.

Ostrom, E. 2005. Understanding institutional diversity. Princeton: Princeton University Press.

Paulson, S. 2017. Degrowth, culture, power and change. Journal of Political Ecology 24: 425-448.

Pickerill, J. 2013. Permaculture in practice: low impact development in Britain. In Lockyer, J. and J. Veteto (eds.) Environmental anthropology engaging ecotopia: bioregionalism, permaculture and ecovillages. New York and Oxford: Berghahn Books.

Schumacher, E.F. 1973. Small is beautiful: economics as if people mattered. London: Blond and Briggs.

Seyfang, G. 2009. The new economics of sustainable consumption: seeds of change. Basingstoke: Palgrave Macmillan.

Seyfang, G. and A. Smith. 2007. Grassroots innovations for sustainable development: towards a new research and policy agenda. Environmental Politics 16(4): 584-603.

Smith, A., A. Stirling and F. Berkhout. 2005. The governance of sustainable socio-technical transitions. Research Policy 34: 1491-1510.

Stonich, S.C. 1993. "I am destroying the land!" : the political ecology of poverty and environmental destruction in Honduras. Boulder: Westview Press.

Taylor Aiken, G. 2017. Permaculture and the social design of nature. Geografiska Annaler: Series B, Human Geography 99(2): 1-20.

Toledo, V. 2001. Biocultural diversity and local power in Mexico: challenging globalization. In Maffi, L. (ed.). On biocultural diversity: linking language, knowledge and the environment. Washington and London: Smithsonian Institution Press.

Van Est, R. 1999. Winds of change: a comparative study of the politics of wind energy innovation in California and Denmark. Utrecht: International Books.

Veteto, J.R. and J. Lockyer. 2008. Environmental anthropology engaging permaculture: moving theory and practice toward sustainability. Culture, Agriculture, Food and Environment 30(1-2): 47-58.

Wilber, K. 2000. Integral psychology. Boston: Shambala.

Würfel, M. 2012. The ecovillage: a model for a more sustainable, future-oriented lifestyle? RCC Perspectives 8: $11-16$. 